\title{
But... What About My Epistemological Foundations?
}

\author{
RAQUEL ISABEL BARRERA CURIN \\ Univeristé du Québec à Montréal (Canada)
}

\section{Identity or theoretical framework?}

At one time or another, all researchers in mathematics education must face the rather complex question of their epistemological foundations. If we are capable of asking ourselves this question, if we decide to question the foundations of our theories - those we use to do what we do, to choose and pursue our research topics - we have entered a conversational and collaborative space where no question is taboo. I find the kind of freedom provided by this space highly inspiring.

Talking about epistemological foundations brings us naturally to a conversation about theories. Theories and epistemological foundations work in a circular fashion: we can talk about the epistemological foundations of our theories and about the theories allowing us to develop our epistemological foundations. Since I like circles, this doesn't bother me at all. A conversation about theories also leads me to talk about what inspires me when I read, when I listen, when I see or when I write.

Several months ago I saw a poster with the slogan: "It's not me! It's my theoretical framework!" It was the kind of thing that we sometimes see that makes us wonder whether to laugh or cry. After a few seconds this phrase led me to a series of reflections about research in general and my own research in particular, and I said to myself: "One thing is sure. It has to be me, otherwise it isn't my research."

Therefore, I want to briefly speak about what I consider to be my epistemological foundations. They did not come into being from one day to the next, nor did they become a part 
of my research at random. I simply realized that these foundations lie beneath everything I do, and that they become tangible as what inspires me when I act. However, in this act there is also writing, and this writing is hardly easy, since the path I have taken, ordinary as it may be, is something I perceive as extraordinary. Thus, I find myself within a process where I attempt to capture the multiple movements which have brought me here.

So here I go!

\section{Questioning theories, foundations and choices for research}

\section{Inspiration}

Ethical concerns, responsibility, and freedom arise only as one sees the other and oneself, as well as the consequences of one's actions on the other or on oneself, and acts according to whether one wants or does not want those consequences. In other words, to have ethical concerns, to be responsible, to be free, one must see the other and oneself in his or her legitimacy

Humberto Maturana

Several ideas can be either combined or dissociated in the process of construction that we call epistemological foundations. Among these ideas are references to discrimination, acceptance, inclusion, truth, pleasure, fear, reason, thought, ethics, language, love - responsibility for Levinas (1981) or empathy for Varela (Varela et al., 1993) - attachments and transformations.

Some of these ideas attach or detach themselves from others before becoming theories: theories that some will take up, that others will ignore, that someone will probably want to impose or that others will simply like.

Theories are very interesting, because any theory is a rational construction made from certain fundamental non-rational principles that are implicitly recognized, whether they are philosophical, economic, physical [or didactic] theories... Theory is an emotion from which we choose certain fundamental premises. Fundamental premises, whichever ones they are and whatever rational system they are part of, are a-rational; they are implicitly accepted... They can seem reasonable to oneself, but I only accept theories because I like them. (Maturana, 2013)

The theories guiding research in mathematics education become evident starting with our first steps as researchers. Their existence, their applications, and how they confront or complement one another are part of our daily work, and allow us to appreciate their creation and development according to each researcher's needs. Speaking about theories can also involve speaking about a means of interpretation that allows us to approach mathematics education, which would even seem indispensable for researchers.

But this means of interpreting the worlds of math education is based on an epistemology that models and gives meaning not only to what we observe and analyze but also to the way we look at these things. We are dealing with ethics, the very heart of conceptions, the reasons for acting, implementing research, the emergence of worlds and structures, the meeting of their components. Thus, the epistemology of our theoretical approaches must not be unfamiliar or unknown to us; after all, it is what will give us the possibility of creating, constructing and even transforming our field of research. What is our relationship with the epistemological foundations of our theoretical approaches? When and to what extent do these foundations become ours and manifest our relationship not only with our research, but also with 
mathematics, the field that allows our field to exist? In my view, epistemological foundations are precisely that: a becoming (Derrida, 1967) which, if we are aware of it, allows us to make them visible in our research, research with which we share a particular view of worlds, mathematics, and didactics itself.

One idea that I find particularly interesting proposes a fundamental difference: our foundations are not the same as our theories, but they underpin them. Thus, our theories can change, evolve, and if one day they no longer suit us, we can even abandon them since they are merely theories and not dogmas or doctrines.

According to Maturana, any theory is refutable,

inasmuch as we can ask ourselves if we wish to continue upholding the foundations or the fundamental principles it was built upon... But for that I have to be ready to question myself about its foundations, and what often happens is that we have theories that we don't want to question, or we even deny the possibility of questioning their foundations, and we transform them into doctrines, and therefore into dogmas. (2013)

This kind of blind absolutism is what I think should never occur. If I ever took paths like these ones as foundations for my research, I would inevitably fall toward discrimination and denying the legitimacy of others. 'All discrimination is based on a theory that denies the act of love, and we are the present of a history and of a theory that justifies the negation of others' (Maturana, 2013). This kind of discrimination becomes explicit even in our research when there is no reflection, when our ideas are in conflict, when we deny others' existence by refusing to listen, believing that we hold the keys to the truth, when we use these absolute convictions to defend, justify, or also to refuse what is happening around us. What a huge danger this is in academia! If we believe we hold the keys to the truth there is nothing left to learn, and nothing new can appear.

Possessing the truth prevents reflection. The enemy of reflection is the possession of knowledge. If I know, why would I abandon what I already say, what I know? I hold the truth, I take it, I don't reflect. We become rigid [...]. In order to be able to reflect we must abandon our attachments, we must move within a space of exchange without prejudice, expectations, or hypotheses toward ourselves or toward others, and that is love... Expectations, hypotheses, and requirements make it impossible to see [or know] others. Knowing is allowing something to appear so that we can look at it without prejudice, without anticipation. (Maturana, 2013)

If we know that we cannot be masters of the truth, we free ourselves from requirements and we thus discover that there is nothing we must require from others or from ourselves. We do not enter into chaos, either, because life is not chaotic, and we discover that the harmony of life is in coexistence, in the acceptance of others. (Maturana, 1992)

All of the elements and ideas I have referred to in this text are mixed with my own experiences, and they are part of my history and of the structure that determines who I am as a mathematics education researcher. These elements move back and forth, within lines of questioning, actions, constructions, or deconstructions (Derrida, 1967), making up what I know, what $I a m$, and also what $I$ do.

This is my central question: how can my epistemological foundations become visible in what others read into my research, and in my actions (or reactions) with respect to others' foundations? Can I tell the difference between them? Should I not try to combine them? 
In response, I tell myself that my epistemological foundations become visible for myself and for others in my daily actions. Writing, speaking, giving, questioning, researching, sharing, feeling, desiring, allowing, listening, respecting, accepting, liking, not liking, waiting, dreaming... doing. My epistemological foundations are transparent; they move along with me. They allow me to remain, to choose, to evolve, to adapt. Not very easy, is it? Adapting? Luckily, this does not entirely depend on me, because I believe in the structural congruence between myself and the my environment, and in the circularity that produces the uniqueness of doing and knowing (Maturana \& Varela, 1987):

This circularity, this connection between action and experience, this inseparability between a particular way of being and how the world appears to us, tells us that every act of knowing brings forth a world. (p. 26)

Well, yes! I allowed myself to be seduced by such ideas, and I like it! Reading these ideas inspires me. Reading these ideas gives me pleasure, makes me question my actions, and allows me to imagine what my future actions. These ideas gave me a new way of reading, writing, seeing, listening... And these ideas form the foundation of what Maturana calls the biology of love: love as an emotion produced in the act of loving. Love is also one of the ethical foundations of responsibility:

to act in a way that the other arises as a legitimate other does not mean blind acceptance, it only means that the other does not need to justify its existence. When this is the case a relation is possible without prejudice, and both liking and not liking take place in full open responsibility. Liking or not liking another, according to what one sees without the distortion of a prejudice, and acting in responsibility for one's liking or not liking, are acts in love. (Maturana \& Verden-Zöller, 2008, p.39)

You might ask why we should talk about a theory of love in didactics of mathematics. My response: the alternative to love is power, or aggression. Personally, I prefer love inasmuch as love 'is not good or bad in itself, it is only the relational domain in which social life, trust, cooperation, and the expansion of intelligent behavior take place' (Maturana \& Verden-Zöller, 2008, p. 80).

Nevertheless, there are several theories deeply rooted in our society, theories calling for competition, for the defense of absolute truths, theories that would impose a way of doing things, theories that aim to change or make things work based on assumptions, with no sense of empathy or responsibility. Faced with these theories, I can only say: this is not who I am. Neither these theories nor their foundations belong to me.

In conclusion, I would simply like to invite my readers to question our theories with the liberty that human history, and the origins of language and conversation, have given us. The act of questioning transforms our world and we can no longer return to the space where we were beforehand. Each individual generates the world he or she lives in, each individual has the power to choose and the power to reflect (Maturana \& Verden-Zöller, 2008).

'Is it possible to [do] otherwise? [In order to respond] we must ask ourselves what the foundations of the current theory are, and ask ourselves whether we want to continue with those foundations or not' (Maturana, 2013).

Our research is who we are. 


\section{References}

Derrida, J. (1967). L'écriture et la difference, Paris: Seuil.

Lévinas, E. (1981). Éthique et infini, Paris: Fayard.

Maturana, H. \& Varela, F. (1987). The tree of knowledge, Boston, MA: Shambhala.

Maturana, H. \& Verden-Zöller, G. (2008). The origin of the humanness in the biology of love, Exeter: Imprint Academic.

Maturana, H. (1992). El sentido de lo humano, Santiago: Editorial Universitaria.

Varela, F., E. Thompson, E. Rosch, (1993). L'inscription corporelle de l'esprit, Paris: Edition Seuil.

Warnken, C. (2013). Humberto Maturana: Una nueva mirada del vivir. In Rojas, Alejandro (Director), Una Belleza Nueva. Santiago: OtroCanal.

\section{About the Author}

Raquel Isabel Barrera Curin completed her M.A. and Ph.D. in didactics of mathematics at Université Paris Diderot - Paris 7 and continued her education as a postdoctoral fellow in the departments of mathematics (supervised by Jérôme Proulx) and education (supervised by Jacinthe Giroux) at Université du Québec à Montréal (UQAM). Earlier, she worked for five years as a primary and secondary school math teacher in Santiago de Chile and for two years training teachers in France (Université de Montpellier 2) and training both mainstream and special education teachers in Quebec (UQAM). Her research interests include students' mathematical work, semiotic mediation, students' and teachers' explorations of relationships between numbers and geometry, languaging, and epistemology. She was recently named as a professor of mathematics education at the department of special education at Université du Québec à Montréal.

(C) Copyright 2015. The author, RAQUEL ISABEL BARRERA CURIN, assigns to the University of Alberta and other educational and nonprofit institutions a non-exclusive license to use this document for personal use and in courses of instruction provided that the article is used in full and this copyright statement is reproduced. The authors also grant a non-exclusive license to the University of Alberta to publish this document in full on the World Wide Web, and for the document to be published on mirrors on the World Wide Web. Any other usage is prohibited without the express permission of the authors. 